\title{
Penetration of the left ventricular myocardium by benign peptic ulceration: two cases and a review of the published work
}

\author{
C PORTEOUS, D WILLIAMS, A FOULIS, BA SUGDEN \\ From the Departments of Surgery and Pathology, Western Infirmary, Glasgow
}

SUMMARY Two cases of penetration of the left ventricular myocardium by benign peptic ulcer are reported. Twenty five similar cases in the world published work are reviewed. The condition is only possible when there are fibrous adhesions between the stomach and diaphragm and the pericardium. In addition, the left lobe of the liver may be small. Alternatively, an ulcer within a hiatus hernia may erode into the left ventricle.

Erosion of a benign peptic ulcer into the myocardium of the left ventricle is rare, and fistulae between the left ventricle and stomach are very rare. There are 21 cases in the world published work, each describing a fistula between a benign peptic ulcer of the stomach and the left ventricle of the heart. In addition, there are four cases in which the myocardium of the left ventricle was penetrated but no fistula formed (Table). We report a further two cases in which a peptic ulcer has eroded into the heart. The first had a fistula between a benign gastric ulcer and the left ventricle. In the second case the connection was between a chronic gastric ulcer and the right coronary artery.

\section{Case reports}

\section{CASE 1}

An 86 year old woman presented with light headedness and haematemesis. She had no acute abdominal pain but had a short history of melaena. Seven years previously she had collapsed and results of investigations had shown iron deficiency anaemia, which was thought to be due to chronic blood loss from a fixed sliding hiatus hernia diagnosed by barium meal. Five years later she was-again admitted after a collapse. An electrocardiogram showed a subendocardial anterolateral infarction. Twelve months later she had a brisk haematemesis after treatment with naproxen for osteoarthritis. This was followed six months later by a further episode of haematemesis. These gastrointestinal bleeds were all attributed to her hiatus hernia, and after her fourth episode she

Accepted for publication 8 August 1984 received cimetidine. On admission, after her fifth haematemesis, she was pale, her pulse rate was 120 beats $/ \mathrm{min}$, and her blood pressure was $90 / 60 \mathrm{mmHg}$. Her abdomen was not tender. Rectal examination showed melaena, and haemoglobin concentration was $7.8 \mathrm{~g} / \mathrm{dl}$. She remained in a stable condition for $6 \mathrm{~h}$, but she then vomited bright red blood several times and became profoundly shocked. In spite of aggressive resuscitation she died.

\section{Pathological findings}

The oesophagus and stomach were full of blood. There was a hiatus hernia of $6 \mathrm{~cm}$ diameter fixed to the left side of the pericardium by fibrous adhesions and also to the left lateral aspect of the heart. The hernia was of the sliding type and was partially reducible. Pressure on the stomach reinflated the hernia and also caused blood to re-enter the heart. A $2.5 \mathrm{~cm}$ diameter benign gastric ulcer in the hiatus hernia had eroded through the pericardium and the myocardium of the left ventricle to form a fistula, which entered the left ventricle just anterior to the posterior mitral cusp (Fig. 1). Adjacent cardiac muscle showed old ischaemic fibrosis, the distribution of which was in keeping with the clinical history of an anterolateral infarction. A probe of $2 \mathrm{~mm}$ diameter could be passed into the heart through the fistula (Fig. 2). Small coronary vessels in the myocardium surrounding the ulcer showed pronounced endarteritis obliterans.

\section{CASE 2}

A 76 year old woman presented as an emergency having collapsed. A recent bowel motion was described as consisting of 1 litre of dark red material. There was no history of pain and at no time did 


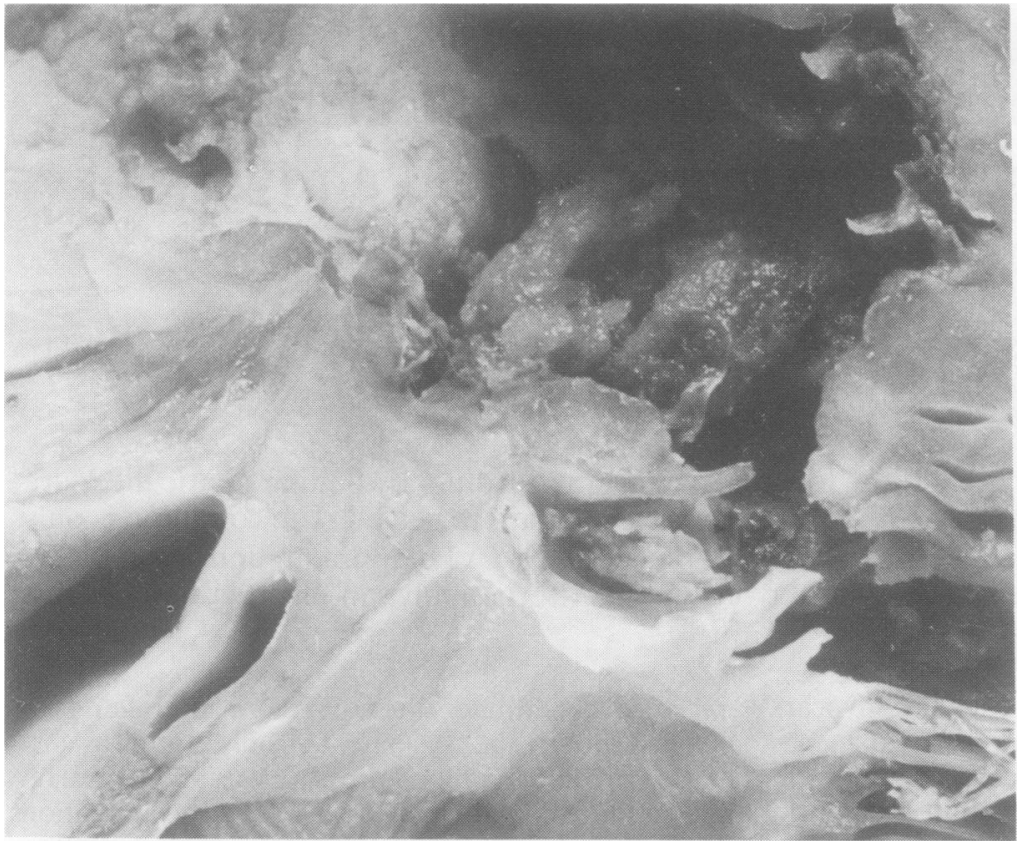

Fig. 1 A chronic peptic ulcer on the right hand side of this figure has eroded into the left ventricle just below the mitral valve.

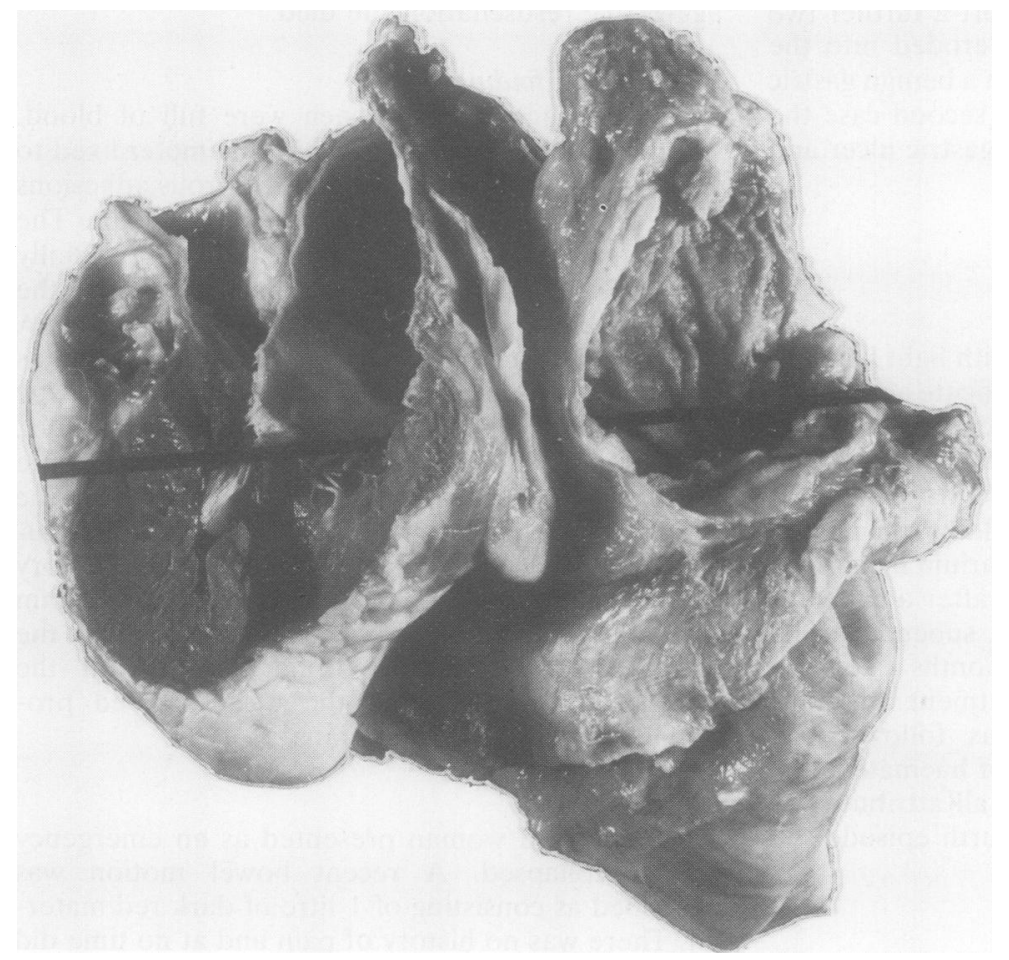

Fig. 2 A probe entering the hiatus hernia and passing through the fistula emerges within the right ventricle. 


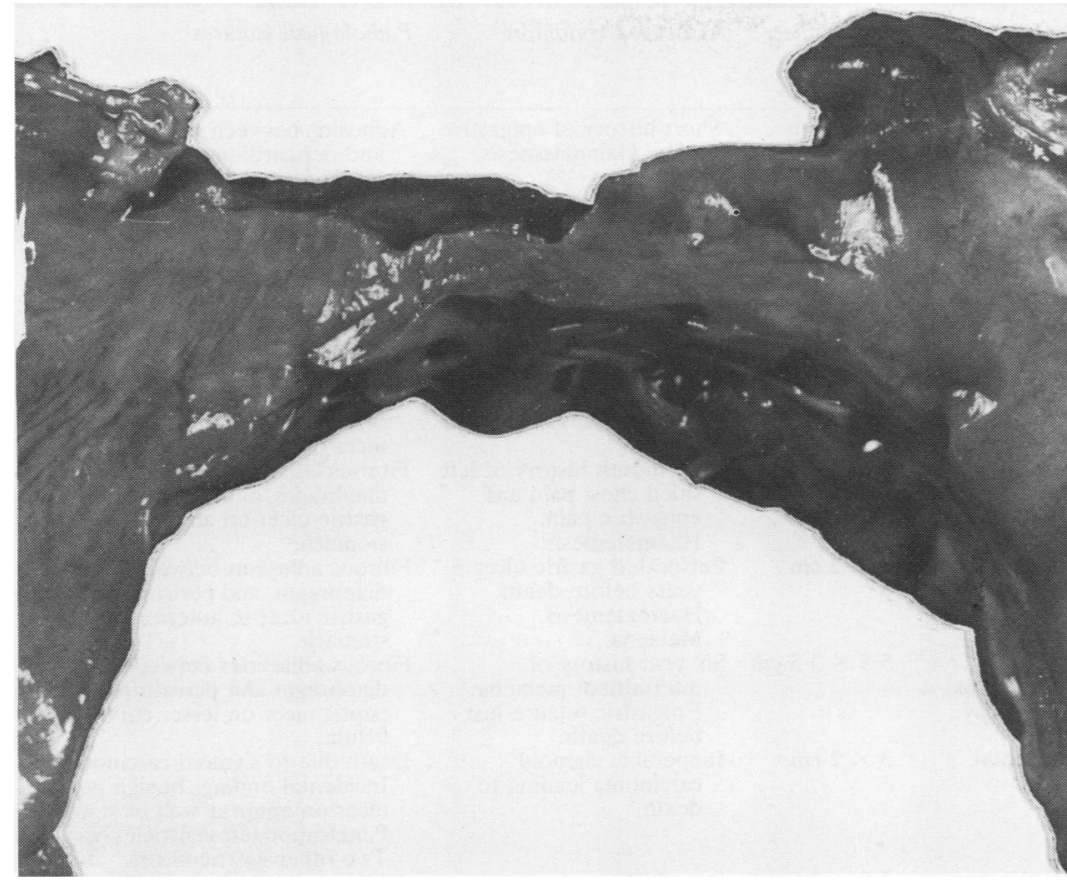

Fig. 3 Only 2 mm of myocardium is left between the base of this chronic peptic ulcer and the lumen of the left ventricle of the heart.

she vomit any blood. Four months previously she had had an inferior myocardial infarction. On examination she was pale and breathless at rest. Her pulse rate was 90 beats/min, blood pressure 100/60 $\mathrm{mmHg}$, and she was not feverish. The abdomen was not tender and bowel sounds were active. Rectal examination showed dark red clotted blood. Haemoglobin concentration was $7.6 \mathrm{~g} / \mathrm{dl}$ and she was therefore transfused six units of packed cells. An electrocardiogram showed the old inferior myocardial infarction with some further acute changes evident in the anterior leads. Diverticulitis was thought to be the cause of this haemorrhage and therefore endoscopy was not performed. Initially, she responded well to conservative treatment, but during the next nine days she had several episodes of melaena and hypotension, which resulted in the deterioration of her condition and her death.

\section{Pathological fundings}

The left lobe of the liver was small. The fundus of the stomach was adherent to the inferior aspect of the diaphragm normally covered by the liver, and the left ventricle of the heart was joined to this by fibrous adhesions. At that site there was a benign gastric ulcer, $5 \mathrm{~cm}$ in diameter, which had penetrated to within $2 \mathrm{~mm}$ of the lumen of the left ventricle (Fig. 3). Two vessels were evident in the base of this ulcer and these were identified as branches of the right coronary artery. The ulcer had eroded through these vessels, which were the main source of bleeding. There was altered blood in the ileum and colon. A fibrinous pericarditis with a small effusion was noted. There was an area of organising infarction at the apex of the heart in the distribution of the right coronary artery. The base of the ulcer was fibrous with endarteritis of small vessels.

\section{Discussion}

Perforation of the left ventricular myocardium by benign gastric ulceration was first described in 1880 by Oser, ${ }^{1}$ and a more complete pathological description of the same case was provided by Chiari. ${ }^{2}$ Since then, there have been only 20 other cases described in the world published work. Four other cases are described in which the left ventricular myocardium was penetrated but no fistula with the lumen of the heart was identified (Table). The presenting symptom in all but two cases in the series was haematemesis, and in these two cases penetration of the myocardium was an incidental finding at necropsy. Melaena was described in only eight cases. ${ }^{235} 10$ Contrary to what might be expected, exsanguination and rapid death occurred in only four patients, three of whom survived until admission to hospital. Of the 24 patients admitted to hospital 17 survived more than 


\begin{tabular}{|c|c|c|c|c|c|c|c|c|}
\hline Author & Year & Age & Sex & Fistula & $\begin{array}{l}\text { Period between } \\
1 \text { st bleed and } \\
\text { death }\end{array}$ & Size of ulcer & Associated condition & Pathological features \\
\hline $\begin{array}{l}\text { Oser } \\
\text { Chiari }\end{array}$ & 1880 & 71 & $\mathbf{F}$ & & 3.5 days & $2 \times 2 \mathrm{~cm}$ & $\begin{array}{l}\text { Short history of epigastric } \\
\text { pain. Haematemesis. } \\
\text { Melaena. }\end{array}$ & $\begin{array}{l}\text { Adhesion between stomach, diaphragm } \\
\text { and pericardium. Fatty changes in } \\
\text { myocardium. Small piece of glass in } \\
\text { ulcer. Benign ulcer on lesser curve. }\end{array}$ \\
\hline Brenner & 1881 & 55 & $\mathbf{F}$ & Yes & 4 days & $10 \times 8 \mathrm{~cm}$ & $\begin{array}{l}\text { Long history of symptoms } \\
\text { of peptic ulcer. } \\
\text { Haematemesis. Melaena. }\end{array}$ & $\begin{array}{l}\text { Adhesion between stomach, diaphragm } \\
\text { and pericardium. Benign ulcer on } \\
\text { lesser curve. }\end{array}$ \\
\hline Finney $^{3}$ & 1886 & 19 & $\mathbf{M}$ & Yes & $30 \mathrm{~min}$ & $2 \times 3 \mathrm{~cm}$ & $\begin{array}{l}\text { Rheumatic fever. Long } \\
\text { history of left sided chest } \\
\text { pain. Melaena. }\end{array}$ & $\begin{array}{l}\text { Rheumatic pericarditis. Adhesion } \\
\text { between stomach, diaphragm and } \\
\text { pericardium. Benign ulcer on } \\
\text { anterior wall of stomach. }\end{array}$ \\
\hline Brunniche $^{7}$ & 1887 & 40 & $\mathbf{M}$ & Yes & $20 \mathrm{~h}$ & $2 \times 3 \mathrm{~cm}$ & $\begin{array}{l}\text { No history of ulcer. } \\
\text { Haematemesis. Melaena. }\end{array}$ & $\begin{array}{l}\text { Adhesions between stomach, } \\
\text { diaphragm and pericardium. Benign } \\
\text { ulcer on lesser curve. }\end{array}$ \\
\hline Tylecote $^{19}$ & 1913 & 70 & $\mathbf{F}$ & Yes & 3.5 days & $1 \times 1 \mathrm{~cm}$ & $\begin{array}{l}\text { Nine month history of left } \\
\text { sided chest pain and } \\
\text { epigastric pain. } \\
\text { Haematemesis. }\end{array}$ & $\begin{array}{l}\text { Fibrous adhesion between stomach, } \\
\text { diaphragm, and pericardium. Benign } \\
\text { gastric ulcer on anterior wall of } \\
\text { stomach. }\end{array}$ \\
\hline Salmony ${ }^{8}$ & 1922 & 50 & $\mathbf{M}$ & Yes & Found dead & $2 \times 2 \mathrm{~cm}$ & $\begin{array}{l}\text { Perforated gastric ulcer } 5 \\
\text { years before death. } \\
\text { Haematemesis. } \\
\text { Melaena. }\end{array}$ & $\begin{array}{l}\text { Fibrous adhesion between stomach, } \\
\text { diaphragm, and pericardium. Benign } \\
\text { gastric ulcer in anterior wall of } \\
\text { stomach. }\end{array}$ \\
\hline Askanazy $^{20}$ & 1926 & 61 & $\mathbf{M}$ & No & $\begin{array}{l}\text { Incidental } \\
\text { finding at } \\
\text { necropsy }\end{array}$ & $5.5 \times 3.5 \mathrm{~cm}$ & $\begin{array}{l}\text { Six year history of } \\
\text { intermittent melaena. } \\
\text { Epigastric seizure just } \\
\text { before death. }\end{array}$ & $\begin{array}{l}\text { Fibrous adhesions between stomach } \\
\text { diaphragm and pericardium. Benign } \\
\text { peptic ulcer on lesser curve. No } \\
\text { fistula. }\end{array}$ \\
\hline Erhardt $^{22}$ & 1933 & 63 & $\mathbf{F}$ & No & Incidental & $3 \times 2 \mathrm{~cm}$ & $\begin{array}{l}\text { Inoperable sigmoid } \\
\text { carcinoma leading to } \\
\text { death. }\end{array}$ & $\begin{array}{l}\text { Death due to sigmoid carcinoma. } \\
\text { Incidental finding: benign peptic } \\
\text { ulcer on anterior wall of stomach. } \\
\text { Penetration left ventricle. No fistula. } \\
\text { Two other gastric ulcers. }\end{array}$ \\
\hline Wassmer ${ }^{21}$ & 1943 & 61 & $\mathbf{M}$ & No & $\begin{array}{l}\text { No bleeding } \\
\text { noticed }\end{array}$ & $5.5 \times 3.5 \mathrm{~cm}$ & $\begin{array}{l}\text { Long history of peptic } \\
\text { ulcer with haematemesis. } \\
\text { Haematemesis. }\end{array}$ & $\begin{array}{l}\text { Adhesion between stomach, } \\
\text { diaphragm, and heart. Benign ulcer } \\
\text { on anterior wall of stomach. }\end{array}$ \\
\hline Johannessen $^{5}$ & 1946 & 40 & $\mathbf{M}$ & Yes & 5 days & $3 \times 2 \mathrm{~cm}$ & $\begin{array}{l}\text { No history. Haematemesis. } \\
\text { Melaena. }\end{array}$ & $\begin{array}{l}\text { Adhesions between stomach, } \\
\text { diaphragm, and heart. Benign peptic } \\
\text { ulcer on lesser curve. }\end{array}$ \\
\hline Dietrich $^{8}$ & 1947 & 49 & $\mathbf{M}$ & Yes & & $2 \times 2 \mathrm{~cm}$ & $\begin{array}{l}\text { Three year history of } \\
\text { symptoms of peptic } \\
\text { ulcer. Haematemesis. }\end{array}$ & $\begin{array}{l}\text { Paraoesophageal hiatus hernia with } \\
\text { benign peptic ulcer. Left lobe of liver } \\
\text { normal. }\end{array}$ \\
\hline Rappert $^{23}$ & 1950 & 71 & $\mathbf{M}$ & Yes & $36 \mathrm{~h}$ & $2 \times 2 \mathrm{~cm}$ & No relevant history. & $\begin{array}{l}\text { Adhesions between stomach, } \\
\text { diaphragm, and pericardium. Benign } \\
\text { ulcer in lesser curve of stomach. }\end{array}$ \\
\hline Ladanyi ${ }^{12}$ & 1954 & 54 & $\mathbf{M}$ & Yes & $24 \mathrm{~h}$ & $3 \times 3 \mathrm{~cm}$ & $\begin{array}{l}\text { Long history of gastric } \\
\text { ulcer. Haematemesis } \\
\text { resulted in laparotomy. } \\
\text { Fistula diagnosis during } \\
\text { operation. Patient died } \\
\text { during operation. }\end{array}$ & $\begin{array}{l}\text { Adhesions between stomach, } \\
\text { diaphragm, and pericardium. Benign } \\
\text { peptic ulcer on lesser curve. }\end{array}$ \\
\hline Pendel $^{15}$ & 1958 & 79 & $\mathbf{F}$ & Yes & $30 \mathrm{~h}$ & $3 \times 2 \mathrm{~cm}$ & $\begin{array}{l}\text { Short peptic ulcer history. } \\
\text { Recent myocardial } \\
\text { infarction. } \\
\text { Haematemesis. }\end{array}$ & $\begin{array}{l}\text { Para oesophageal hiatus hernia. Benign } \\
\text { peptic ulcer. }\end{array}$ \\
\hline Bittman (1)"1 & 1960 & 44 & $\mathbf{M}$ & Yes & $\begin{array}{l}60 \mathrm{~h} \text { to } \\
\text { operation. } \\
24 \mathrm{~h} \text { after } \\
\text { operation. }\end{array}$ & $5 \times 5 \mathrm{~cm}$ & $\begin{array}{l}\text { Long peptic ulcer history. } \\
\text { Haematemesis resulting } \\
\text { in laparotomy. Subtotal } \\
\text { gastric resection. Patient } \\
\text { died } 24 \mathrm{~h} \text { after surgery. }\end{array}$ & $\begin{array}{l}\text { Adhesion between stomach, } \\
\text { diaphragm, and heart. Benign peptic } \\
\text { ulcer at resection line. }\end{array}$ \\
\hline Bittman (2) & 1960 & 62 & $\mathrm{~F}$ & Yes & $24 \mathrm{~h}$ & $3.5 \times 3.5 \mathrm{~cm}$ & $\begin{array}{l}18 \text { year history of peptic } \\
\text { ulcer. } \\
\text { Oesophagogastrectomy } \\
\text { for gastric ulcer } 12 \\
\text { months before death. } \\
\text { Heartburn. }\end{array}$ & $\begin{array}{l}\text { Postoperation fibrous adhesion } \\
\text { between stomach, diaphragm, and } \\
\text { heart. Benign peptic ulcer on } \\
\text { resection line. }\end{array}$ \\
\hline Ritz $^{13}$ & 1966 & 69 & $\mathbf{M}$ & Yes & 12 days & $2 \times 2 \mathrm{~cm}$ & $\begin{array}{l}\text { Perforated gastric ulcer } 9 \\
\text { years before death. } \\
\text { Haematemesis resulting } \\
\text { in gastrectomy. Death } \\
24 \mathrm{~h} \text { after operation. }\end{array}$ & $\begin{array}{l}\text { Postoperation fibrous adhesion } \\
\text { between stomach, diaphragm, and } \\
\text { pericardium. Benign peptic ulcer in } \\
\text { fundus of stomach. }\end{array}$ \\
\hline Kissel $^{24}$ & 1964 & 59 & $\mathbf{M}$ & Yes & $20 \mathrm{~h}$ & $2 \times 2 \mathrm{~cm}$ & $\begin{array}{l}\text { No history. Aspirin abuse. } \\
\text { Haematemesis. }\end{array}$ & $\begin{array}{l}\text { Fibrous adhesions between stomach, } \\
\text { diaphragm, and pericardium. Small } \\
\text { left lobe of liver. Benign peptic ulcer } \\
\text { on lesser curve. }\end{array}$ \\
\hline
\end{tabular}




\begin{tabular}{|c|c|c|c|c|c|c|c|c|}
\hline Author & Year & Age & Sex & Fistula & $\begin{array}{l}\text { Period between } \\
\text { Ist bleed and } \\
\text { death }\end{array}$ & Size of ulcer & Associated condition & Pathological features \\
\hline Meinecke $^{17}$ & 1967 & 39 & $\mathbf{M}$ & Yes & $10 \mathrm{~h}$ & $3 \times 3 \mathrm{~cm}$ & $\begin{array}{l}\text { Long history of peptic } \\
\text { ulcer disease. } \\
\text { Haematemesis. } \\
\text { Melaena. }\end{array}$ & $\begin{array}{l}\text { Adhesions between stomach, } \\
\text { diaphragm, and heart. Benign peptic } \\
\text { ulcer on lesser curve. }\end{array}$ \\
\hline $\mathrm{Kiss}^{25}$ & 1967 & 89 & $\mathbf{F}$ & Yes & $10 \mathrm{~h}$ & $3 \times 1.5 \mathrm{~cm}$ & $\begin{array}{l}\text { Long history of hiatus } \\
\text { hernia. Haematemesis. }\end{array}$ & $\begin{array}{l}\text { Hiatus hernia with peptic ulcer. } \\
\text { Fibrinous pericarditis. }\end{array}$ \\
\hline Grosse $^{y}$ & 1970 & 69 & $\mathbf{M}$ & Yes & $20 \mathrm{~min}$ & $3 \times 2 \mathrm{~cm}$ & $\begin{array}{l}\text { Cahexia. Myocardial } \\
\text { infarction. } \\
\text { Haematemesis. }\end{array}$ & $\begin{array}{l}\text { Adhesions between stomach, } \\
\text { diaphragm, and pericardium. } \\
\text { Chronic peptic ulcer on anterior } \\
\text { surfaces of stomach. }\end{array}$ \\
\hline Maroske $^{16}$ & 1972 & 59 & $\mathbf{M}$ & Yes & $20 \mathrm{~min}$ & $10 \times 8 \mathrm{~cm}$ & $\begin{array}{l}\text { Left phrenic nerve } \\
\text { paralysis and left } \\
\text { diaphragm elevation } \\
\text { after war injury. Long } \\
\text { history of left sided } \\
\text { abdominal pain. } \\
\text { Haematemesis. }\end{array}$ & $\begin{array}{l}\text { Left diaphragm raised and adherent to } \\
\text { the left lobe of liver, heart, and left } \\
\text { lung. Left lobe of liver normal size. } \\
\text { Ulcer penetrated liver, diaphragm, } \\
\text { and left ventricle. Severe endarteritis } \\
\text { resulting in myocardial infarction. }\end{array}$ \\
\hline $\mathrm{Lam}^{26}$ & 1974 & 67 & $\mathbf{M}$ & $\begin{array}{l}\text { Yes and } \\
\text { to left } \\
\text { atrium. }\end{array}$ & 2 days & $3 \times 2 \mathrm{~cm}$ & $\begin{array}{l}\text { Gastric carcinoma } \\
\text { resected. Haematemesis. }\end{array}$ & $\begin{array}{l}\text { No evidence of local recurrence of } \\
\text { gastric ulcer. Fistula with left } \\
\text { ventricle and left atrium suggested it } \\
\text { may have been due to ischaemia. }\end{array}$ \\
\hline Matthews $^{14}$ & 1974 & 71 & $\mathrm{~F}$ & No & 6 days & $6 \times 3 \mathrm{~cm}$ & $\begin{array}{l}\text { Previous history of peptic } \\
\text { ulcer disease. Hiatus } \\
\text { hernia. Myocardial } \\
\text { ischaemia. Atrial } \\
\text { ectopics. Intermittent } \\
\text { left bundle branch block. }\end{array}$ & $\begin{array}{l}\text { Left circumflex coronary artery in } \\
\text { bases of ulcer and source of bleeding } \\
\text { fibrous adhesions. }\end{array}$ \\
\hline Kennedy ${ }^{10}$ & 1983 & 81 & $\mathbf{F}$ & Yes & $8 \mathrm{~h}$ & $3 \times 1 \mathrm{~cm}$ & Hiatus hernia. & $\begin{array}{l}\text { Pericardial cavity obliterated by } \\
\text { adhesions. Fibrosis and endarteritis } \\
\text { Obliterans in the underlying } \\
\text { myocardium. }\end{array}$ \\
\hline
\end{tabular}

$6 \mathrm{~h} ; 13$ of those survived more than $24 \mathrm{~h}$, the mean period of survival being three days. A possible explanation for this remarkable feature was first postulated by Grosse, ${ }^{9}$ who thought that hypotension together with the tamponading effect of a stomach turged with blood would be enough to stop the haemorrhage, at least for a limited period. Despite this, surgery was attempted in only four cases, ${ }^{1-14}$ and in no case was the diagnosis made clinically. Myocardial infarction was diagnosed

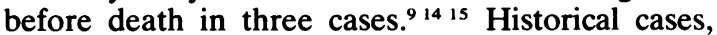
however, may have lacked modern techniques for diagnosing myocardial infarction. One other case had pathological evidence of myocardial infarction. ${ }^{16}$ Fourteen cases had a previous history suggestive of peptic ulcer disease. ${ }^{1811-1315-20}$ The ulcers tended to be large with a mean diameter of 3 cm. All ulcers were histologically benign chronic peptic ulcers. The only unusual ulcer, in which a small piece of glass was found in the base, was described by Chiari. ${ }^{2}$ Endarteritis obliterans is a commonly described feature. Only Chiari and Tylecote ${ }^{19}$ described fatty change in the myocardium surrounding the ulcer. Twenty cases were associated with fibrous adhesions between the stomach and diaphragm..$^{135-911-1316-24}$ Only five reports described cases where this was not a feature. In each case the ulcer had developed within a paraoesophageal hiatus hernia. Kissel ${ }^{24}$ pointed out that the fundus or lesser curve of the stomach must come into contact with the inferior aspect of the diaphragm for a fistula to develop and that a small left hepatic lobe should be found in each case. In the case described by Grosse ${ }^{9}$ and Maroske ${ }^{16}$ however, the left lobe of the liver was normal in size but, in addition, the liver had been penetrated by the ulcer. In the second case presented here the left lobe of the liver was notably small. Absence of fibrous adhesions between visceral and parietal pericardium results in a pneumopericarditis ${ }^{27}$ but no fistula. Four cases have been described in which a chronic gastric ulcer penetrated the myocardium of the left ventricle but failed to establish a fistula ${ }^{14} 1^{18-20}$ as in case 2 . Three of these were incidental findings at necropsy. The other case reported by Matthews ${ }^{14}$ was similar to our second case in that the source of the blood in the haematemesis was a coronary artery. Lam $^{24}$ described a case where the perforation was at the atrioventricular junction, resulting in a fistula between the stomach and both the left atrium and ventricle.

\section{Conclusion}

Three features allow a peptic ulcer to penetrate the heart. Firstly, the ulcer may be located high in the stomach or within a hiatus hernia; secondly, there must be fibrous adhesions between the stomach, 
diaphragm, and pericardium; and, thirdly, the left lobe of the liver may be small, allowing the stomach to come into contact with the diaphragm.

No patient has yet survived this rare condition. The advent of modern fibreoptic equipment and routine endoscopy after haematemesis, however, makes early diagnosis feasible. An awareness that a major haematemesis is from a chronic ulcer in the lesser curve or fundus of the stomach, together with a history of pericarditis with or without a myocardial infarction, should alert doctors to the possibility of penetration of the left ventricle.

We thank Dr A Reid, Lecturer in Pathology, University Department of Pathology, Leeds, for his assistance in translating these references. Professors WD George, WR Lee, RNM MacSween, and Dr PF MacFarlane helped with advice and photographic work was performed by Mr P Kerrigan and Mr J Hendry.

\section{References}

' Oser P. Em Fall von Perforation eines runden Magengeschwures in das linken. Wiener Medizinische Blätter 1880 No 52 (Quoted by JM Finney).

${ }^{2}$ Chiari H. Fall von Perforation eines runden Magengeschwures in den linken Herzventrikel, und Demonstrierung des bezuglichen. Praparates. Wiener Medizmische Blätter 1880;3:56870.

${ }^{3}$ Finney JM. Ulcer of the stomach opening into the left ventricle of the heart. Br Med J 1886; 1:1102-4.

${ }^{4}$ Rhodes J. Etiology of gastric ulcer. Gastroenterology 1972; 63: 171 .

5 Johannessen AS. Gastric ulcer with penetration of heart and death from rupture of heart. Nord Med 1946;30:1029-30.

- Brenner F. Perforation eines runden Magengeschwures in den linken Herzventrikel. Wien Med Wochenschr 1881;31:1310.

' Brunniche, A. Et Sjaeldent Tilfoelde af Ulcus perforans Ventriculi. Hospitals Tidende, Kjobenhavn 1887;3:RVB:697.

${ }^{8}$ Salmony L. Durchbruch eines Magengeschwurs in die linke Herzkammer. Zbl Allg Path Anat 1922;32: 225.

${ }^{9}$ Grosse H. Perforation eines Magengeschwures in die linke Herzkammer. Dischgesundheitsw 1970;25:607-8.

${ }^{10}$ Kennedy H. Peptic ulceration affecting the left ventricle. Thorax 1983;38:630-1.
" Bittman O, Kralik J, Dusek J, Mur J. Perforation eines hohen Magengeschwurs in die linke Herzkammer. Zentralbl Chir 1960;85: 1379.

${ }^{12}$ Ladanyi J, Haraszti A. A bal szivkamra falaba attort gyomorfekely. Orvosi Hetilap 1954;29:790.

${ }^{13}$ Ritz A, Fischer R. Perforation eines Ulcus ventriculi in die linke Herzkammer. Schweiz Med Wochenschr 1966;96:327.

${ }^{14}$ Matthews HR. Haematemesis from a coronary artery caused by penetration of a gastric ulcer in a hiatus hernia. Br Heart $J$ 1974;36:1141-3.

is Pendel O. Durchbruch eines peptischen Magengeschwurs in die linke Herzkammer. Wien Klin Wochenschr 1958;70:301.

${ }^{16}$ Maroske D, Drews H, Schmitz-Moormann P. Linksseitiger Zwerchfellhochstand in Folge einer Durch Granatsplitter bedingten Phrenicusparese als ursache fur eine Perforation eines Ulcus ventriculi in die linke Herzhammer. Chirurgie 1972; 43:337-42.

${ }^{17}$ Meinecke FW. Aus Unfallakten durchbruci eines Magengeschwurs in die linke Herzkammer. Monatsschrift fur Unfallheilkunde Und. Versischerlungmediz 1967;70:135-6.

${ }^{18}$ Dietrich A. Hiatushernie, Angina pectoris, Geschwursbildung mit Einbruch in die linke Herzkammer. Hippokrates 1947; 18:279.

${ }^{19}$ Tylecote FE. A note on perforation of gastric ulcers into the heart itself, with report and photograph of a case. Lancet 1913;ii: $1613-4$.

${ }^{20}$ Askanazy M. Uber Nervenwucherungen im chronischen Magengeschwur und uber ein Magenherzgeschwur. Schweiz Med Wocherschr 1926;27:661.

${ }^{21}$ Wassmer F. L'Ulcere Gastrique Penetrant Le Myocarde. These No 1800 (1943). Marburg University.

${ }^{22}$ Ehrhardt W. Durchbruch eines Magengeschwurs in die Wand der linken Herzkammer. Virchows Arch [Pathol Anat]1933; 289:327.

${ }^{23}$ Rappert E. Penetration eines Magenulcus in die lnke Herzkammer. Klin Med (Wien) 1950;2:367.

${ }^{24}$ Kissel P, Schmidt J, Barrucand D, Vaillant G, Reny J. Hemorragie Digestive Secondaire a La Perforation d Un Ulcere Gastrique dans Le Ventricule Gauche. (A propos d' une observation anatomo-clinique). Nn Med Nancy 1964;3:1022-8.

${ }^{25}$ Kiss L. A Sziv Bal Kamra Jaba Perforalt Idult Gyomorfekely. Orvosi Hetilap (Hungary) 1967; 108:656-8.

${ }^{26}$ Lam CR, Angulo AE, Priest RJ. Recurrent ulcer of the thoracic stomach penetrating the heart. Report of a case and review of the Literature. J Thorac Cardiovasc Surg 1975;69:835-8.

${ }^{27}$ Romhilt DW, Alexander JW. Pneumopyopericardium secondary to perforation of benign gastric ulcer.JAMA 1965;191:140-2.

Requests for reprints to: Mr C Porteous, University Department of Surgery, Western Infirmary, Glasgow, Scotland. 